\title{
Metrical and non-metrical study of the pterion in South Indian adult dry skulls with notes on its clinical importance
}

\author{
Güney Hint yetişkin kuru kafataslarında klinik önemi ile birlikte metrik ve metrik olmayan \\ pterion çalışması
}

Sneha Guruprasad KALTHUR, Shnmukha Varalakshmi VANGARA, Lakshmi KIRUBA, Antony Sylvan DSOUZA, Chandni GUPTA

\begin{abstract}
Objectives: The pterional site is important as it lies in close proximity to the middle meningeal artery and on the left side, to Broca's motor speech area. This location is important in surgical approaches to the anterior and middle cranial fossae. This study was conducted to determine the location and type of pterion in a group of South Indian human skulls.
\end{abstract}

Materials and Methods: The study was conducted on 50 dry adult skulls. The distance from pterion to various bony landmarks were measured on both sides using a vernier caliper. In addition, the pterion was classified depending on bones involved in the articulation, its symmetry and its position in the skull.

Results: In the present study a sphenoparietal type of pterion was the most common (78\%). The average distance from the center of the pterion to the frontozygomatic suture was $3.97 \pm 0.10$ $\mathrm{cm}$, to the zygomatic arch was $3.27 \pm 0.06 \mathrm{~cm}$. The average distance from the internal aspect of the center of the pterion to the optic canal was $4.02 \pm 0.12 \mathrm{~cm}$, to the sphenoid ridge was $0.97 \pm 0.09 \mathrm{~cm}$, to the stem of middle meningeal artery was $0.99 \pm 0.07 \mathrm{~cm}$ and to its nearest branches was $0.58 \pm 0.12 \mathrm{~cm}$.

Conclusion: These findings will be useful in relating the position of the pterion to several important landmarks in various surgical approaches.

Keywords: Pterion, Pterional approach, Frontozygomatic suture, Middle meningeal artery

Sneha Guruprasad Kalthur, Shnmukha Varalakshmi Vangara, Lakshmi Kuruba, Antony Sylvan Dsouza, Chandni Gupta (四)

Department of Anatomy, Kasturba Medical College, Manipal-576 104, Karnataka, India

e-mail: chandnipalimar@gmail.com

Submitted / Gönderilme: 21.10.2016

Accepted/Kabul: 17.12 .2016

\section{ÖZ}

Amaç: Pterional bölge, orta meningeal arter ve Broca'nın motor konuşma alanının yakınında bulunduğu için önemli, bir bölgedir. Bu neden ile, anterior ve orta kraniyal fossalara cerrahi yaklaşımlarda bu yer önem taşımaktadır. Bu çalışma, Güney Hint insan kafataslarındaki pterion'un yerini ve türünü belirlemek için yapılmıştır.

Gereçler ve Yöntemler: Çalışma 50 kuru yetişkin kafatasında yürütülmüştür. Pterion'dan çeşitli kemikli noktalara olan uzaklık, her iki tarafta da vernik kaliper kullanılarak ölçülmüştür. Buna ek olarak pterion, kemikler eklemli, simetri ve kafatasındaki konumu itibariyle sınıflandırılmıştır.

Bulgular: Çalışmamızda, sfenoparietal pterion en sık (\% 78) rastlanan tip idi. Pterion'un merkezinden frontozigotik dikişe ortalama mesafe 3,97 $\pm 0,10 \mathrm{~cm}$, zigomatik kemer için 3,27 $\pm 0,06$ $\mathrm{cm}$ idi. Ayrıca, pterion'un merkezinden optik kanala içten uzaklık ortalamas1 $4,02 \pm 0,12 \mathrm{~cm}$, sfenoid sirtına $0,77 \pm 0,09 \mathrm{~cm}$, orta meningeal artere $0,99 \pm 0,07 \mathrm{~cm}$ ve en yakın dallarına $0.58 \pm 0.12$ cm idi.

Sonuç: Bu bulgular, çeşitli cerrahi operasyonlarda pterion'un yerinin tam olarak belirlenmesinde yararlı olacaktır.

Anahtar kelimeler: Pterion, Pterional yaklaşım, Frontozigomatik sütür, Orta meningeal arter

\section{Introduction}

The pterion is an irregular ' $\mathrm{H}$ ' shaped suture present on the lateral aspect of skull where the squamous part of the temporal bone meets the frontal, sphenoid, and parietal bones. In general, the pterion is considered to be located two finger-breadths above the zygomatic arch and a thumb width posterior to the frontal process of the zygomatic bone [1-2].

The pterion forms an important landmark in pathological conditions of many structures that are closely associated with it: including the optic nerve, the orbit, the sphenoidal ridge, the middle cerebral artery, particularly its aneurysms 
and trauma to middle meningeal artery [3-6]. Apart from its importance as a surgical landmark it also can be a guide for determing the age, sex and race in archeological and forensic specimens [7,8]. Metrical and non-metrical studies on the pterion are available in the literature [5,9]. Owing to its variation in metrical and non-metrical parameters with respect to race, gender and geographical distribution, studies on the pterion play a significant role in surgical anatomy. In the present study, we report the variations in types of pterion and its relation to the neighboring anatomical landmarks in adult South Indian dry skulls.

\section{Materials and Methods}

In the present study 50 dry adult skulls (37 males, 13 females) were obtained from the Department of Anatomy, Kasturba Medical College, India. The skulls were divided by a cut at the upper part of the cranium about two $\mathrm{cm}$ above the supraorbital margin anteriorly and the inion posteriorly. The pterions were classified on the basis of the bones articulating, and their positions as well as their bilateral symmetry. The distance between the pterion and specific identifiable bony landmarks were measured from the external and internal aspects on both sides of the skull, using a vernier caliper as described by Murphy [10].

\section{Classifications of Pterions}

\section{a. Based on bones articulating (Figure 1)}

1. Sphenoparietal: defined as a sutural pattern where the sphenoid bone articulates with the parietal bone directly.

2. Frontotemporal: defined as a sutural pattern where the frontal bone comes in direct contact with temporal bone.

3. Stellate: characterized by articulation of all four bones, that is sphenoid, parietal, frontal, temporal bones at one point.

4. Epipteric: defined by the presence of small sutural bone between parietal and the sphenoid bone.

Epipteric types were further classified (Figure 2) as described by Ersoy et al. [3]:

a) Os epiptericum proprium - epipteric bones articulates with all constituents of pterion.

b) Os epiptericum triquadrum - a single epipteric bone articulates with three bony constituents of the pterion either anteriorly (Os epiptericum antericus), posteriorly
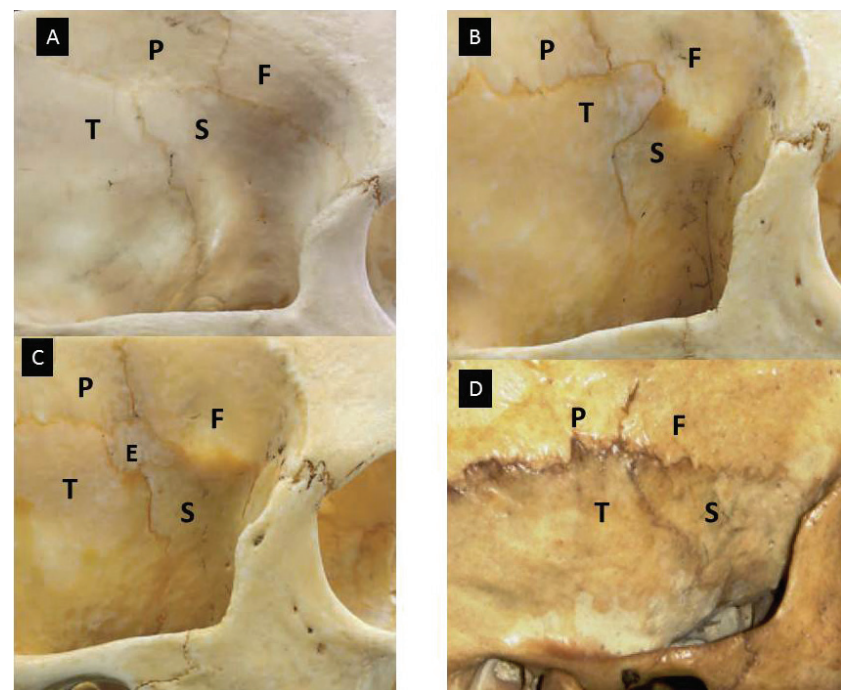

Figure 1: Various types of pterion

A Sphenoparietal B Frontotemporal C Epipteric D Stellate

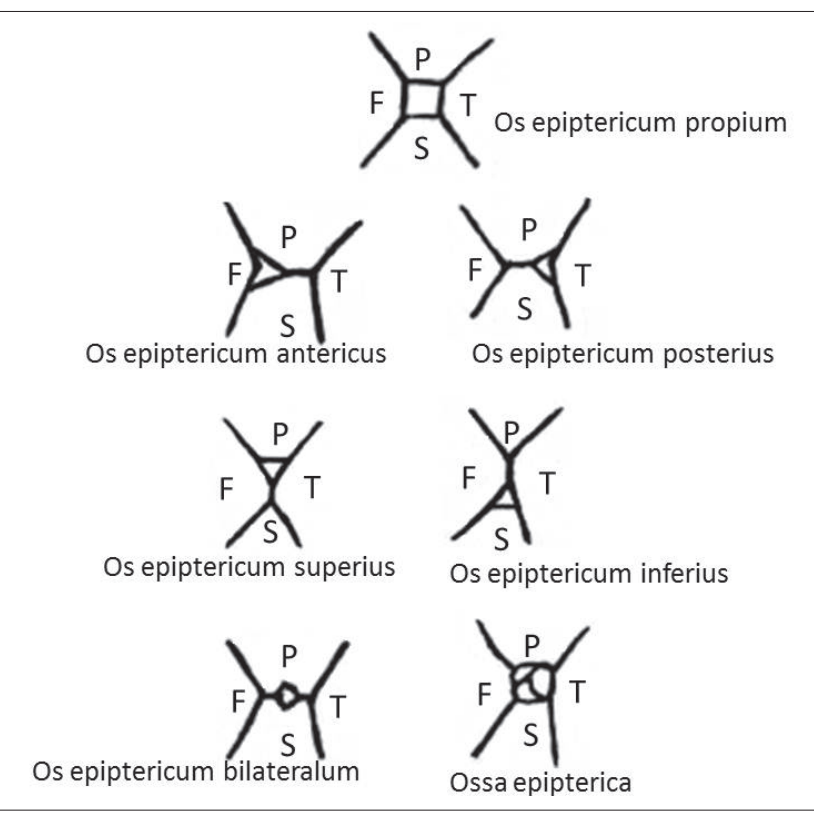

Figure 2: Sub classification of epipteric bones

$\mathrm{F}=$ Frontal bone

$\mathrm{P}=$ Parietal bone

$\mathrm{T}=$ Temporal bone

$\mathrm{S}=$ Sphenoid bone

(Os epiptericum posterius), inferiorly (Os epiptericum inferius) or superiorly (Os epiptericum superius).

c) Os epiptericum bilateralum - epipteric bones lie in between two constituents of the pterion.

d) Ossa epipterica - multiple epipteric bones are present in the pterion. 


\section{b. Based on symmetry}

The pterions were studied in each skull to identify whether they were bilaterally symmetrical. Based on the various articulating bones in the formation of pterion, 16 combinations are possible (four bilaterally symmetrical combinations with the same type on the right and left sides, and 12 bilaterally asymmetrical combinations with different types on the right and left sides [10].

\section{c. Based on position}

The pterions were also classified based on their position in the skull as:

1. High pterion - distance $>4 \mathrm{~cm}$ from the zygomatic arch

2. Low pterion - distance $<3.9 \mathrm{~cm}$ from the zygomatic arch

3. Anterior pterion - distance $<3 \mathrm{~cm}$ from the frontozygomatic suture

4. Posterior pterion - distance $>3.1 \mathrm{~cm}$ from the frontozygomatic suture.

\section{Metrical parameters}

The location of pterion was assessed by drawing a circle with the smallest radius connecting all the four bones involved in the formation of the pterion, the center of which was marked as the center of the pterion (Figure 3).

\section{Measurement from external aspect (Figure 3a)}

$A=$ the vertical distance from the center of the pterion to the zygomatic arch

$\mathrm{B}=$ the distance from the center of the pterion to the posterolateral aspect of the frontozygomatic fissure

\section{Measurements from internal aspect (Figure 3b)}

$\mathrm{C}=$ horizontal distance from the center of the pterion to the lateral margin of the optic canal

$\mathrm{D}=$ distance from the central of the pterion to the lateral end of the ridge on the lesser wing of the sphenoid

$\mathrm{E}=$ distance from the pterion to nearest point of stem of MMA

$\mathrm{F}=$ distance from the pterion to nearest point of branch of MMA

The relation of the pterion to the middle meningeal artery (MMA) (Figure 3c)

$\mathrm{G}=$ pterion to anterior end of anterior ramus of MMA

$\mathrm{H}=$ pterion to posterior end of posterior ramus of MMA

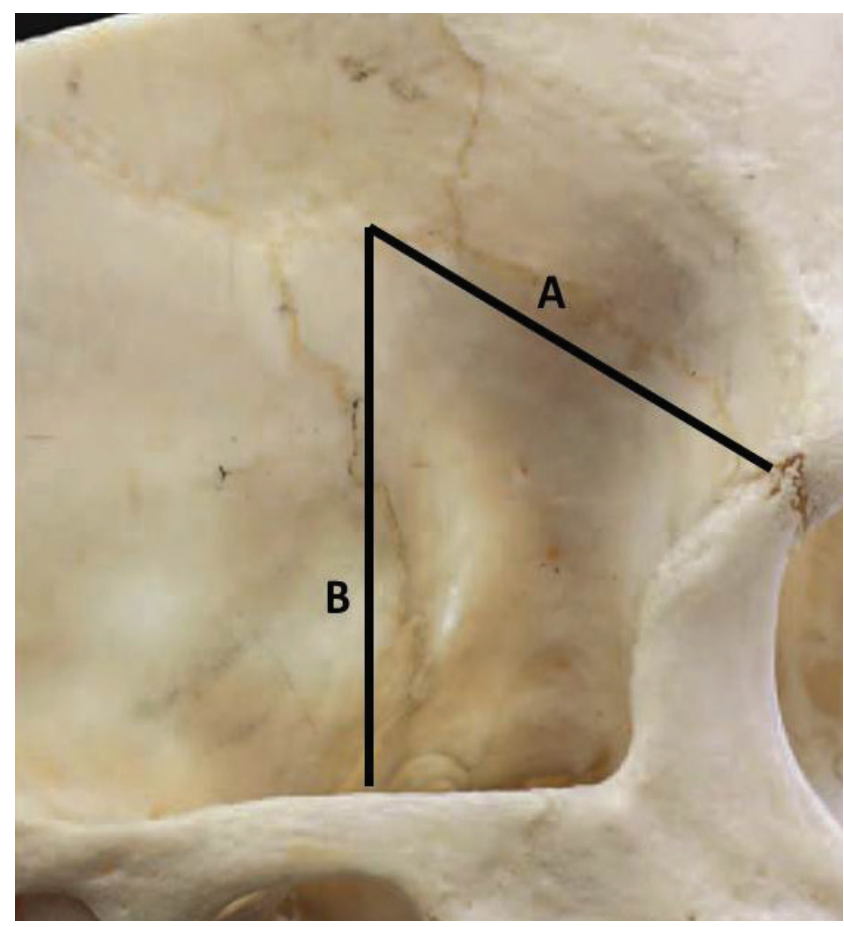

Figure 3a: Measurements taken from external aspect of each skull $\mathrm{A}=$ vertical distance from the center of the pterion to the zygomatic arch

$\mathrm{B}=$ distance from the center of the pterion to the frontozygomatic fissure

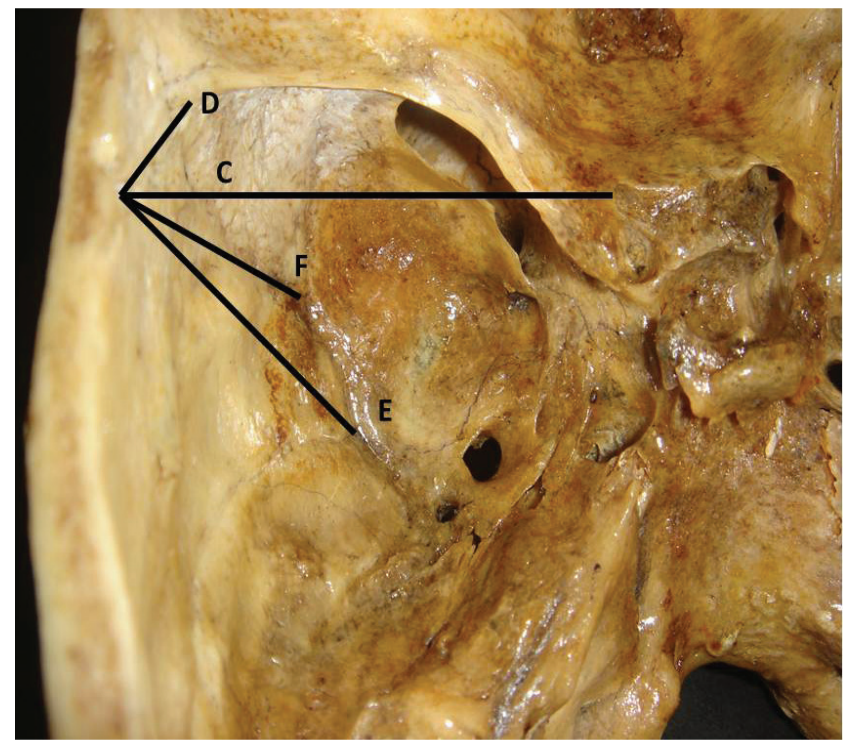

Figure 3b: Measurements taken from internal aspect of each skull $\mathrm{C}=$ horizontal distance from the internal aspect of the center of the pterion to the lateral margin of the optic canal

$\mathrm{D}=$ distance from the internal aspect of the center of the pterion to the lateral end of the ridge on the lesser wing of the sphenoid $\mathrm{E}=$ distance from the pterion to the nearest point of the stem of the MMA

$\mathrm{F}=$ distance from the pterion to the nearest point of the branch of the MMA 


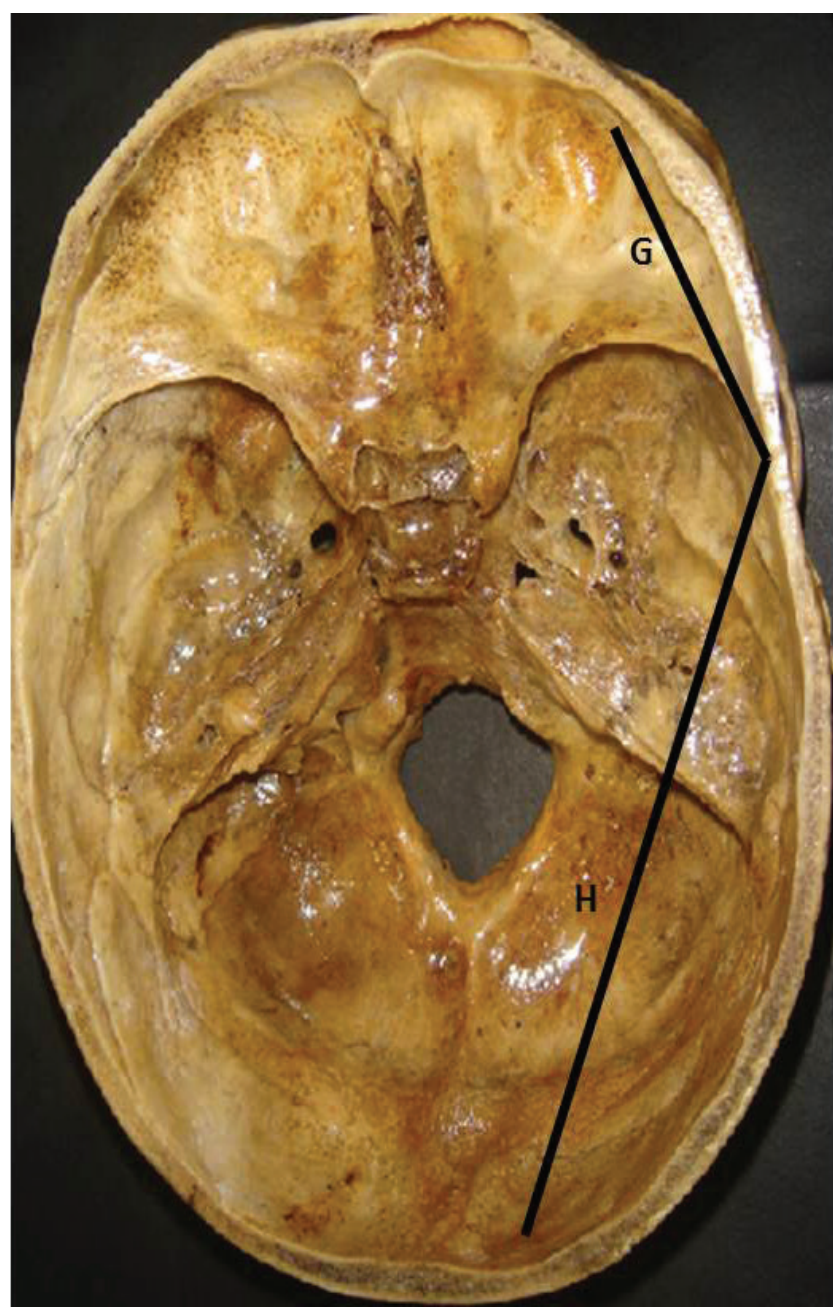

Figure 3c: Relation of the pterion with MMA and its branches this whole thing has to go in figure $3 \mathrm{~b}$. plz put it there. and remove it from $3 \mathrm{c}$ figure.

$\mathrm{G}=$ pterion to anterior end of anterior ramus of MMA

$\mathrm{H}=$ pterion to posterior end of posterior ramus of MMA

\section{Statistical analysis}

The metrical parameters are represented as mean and standard deviation (SD) of the actual values while the other parameters are expressed in percentages. The incidence of various types of pterions were analysed with the Chi square test using SPSS software.

\section{Results}

The present study was carried out on 50 dry adult skulls which were collected from coastal Karnataka. It comprised of 37 male (74\%) and 13 female (26\%) skulls with mean age of 50 .

\section{Classification of the pterion}

\section{a. Based on bones articulating}

The most common type of pterion observed in the present material was sphenoparietal $(78 \%)$ followed by epipteric (17\%) and frontotemporal (4\%) (Table I). The incidence of types of pterion in male and female skulls was similar. Stellate type pterions were least common (1\%). Interestingly, it was observed that none of the male skulls had the frontotemporal variety and no female skulls had the stellate variety (Table I).

When epipteric types of pterion were further classified, of 17 skulls with the epipetric type, only three types - os epipterium proprium, os epipterium posterius and os epitericum antero-superius were observed (Table III). The most common type was os epipterium posterius (52.9\%) followed by os epiptericum proprium type (42.9\%) and os epitericum antero-superius (5.9\%) (Figure 4). In addition, the type of pterion was not always bilaterally symmetrical.

\section{b. Based on symmetry}

Among 50 skulls analyzed 42 (84\%) were bilaterally symmetrical with respect to articulating bones in pterion and remaining 8 skulls (16\%) were asymmetrical with respect to articulating bones in the pterion (Table II). In bilaterally symmetrical pterions only sphenoparietal, frontotemporal and epipteric types were observed. In asymmetrical combinations of the $8(16 \%)$ skulls, 7 were an epipteric and sphenoparietal combination and one skull had stellate and a sphenoparietal combination. In male skulls only sphenoparietal (70.27\%) and epipteric types (10.81\%) were bilaterally symmetrical, while in female skulls only sphenoparietal (69.23\%), frontotemporal (15.38\%) and epipteric types $(7.68 \%)$ were bilaterally symmetrical.

\section{c. Based on position}

When we classified the pterion based on their position in the skull, $48 \%$ were grouped under high and 52\% were grouped under low position. The incidence of high and low pterion was similar for the two sides. The pterions at a high position were more common in males $(60 \%)$ than in females $(15.3 \%)$ whereas the incidence of low pterion was more in females $(84.7 \%)$ than in males $(40 \%)$. When we classified with respect to their distance from the frontozygomatic arch, $27 \%$ were anterior and $73 \%$ were posterior. On the right and left side of the skull, the incidence of a posterior pterion was 
Table I. Types of pterion in adult skulls from the coastal Karnataka region

\begin{tabular}{|l|c|c|c|c|c|}
\hline \multirow{2}{*}{ Types $(\%)$} & \multirow{2}{*}{$\begin{array}{c}\text { Total } \\
(\mathrm{n}=100)\end{array}$} & Right $(\mathrm{n}=50)$ & Left $(\mathrm{n}=50)$ & \multicolumn{2}{c|}{ Sex } \\
\cline { 3 - 6 } & & 70 & $86^{\mathrm{b}}$ & 79.75 & Female $(\mathrm{n}=74)$ \\
\hline Sphenoparietal & $78^{\mathrm{a}}$ & 4 & 4 & 0 & 13 \\
\hline Frontotemporal & 4 & 24 & 10 & 18.9 & 11.6 \\
\hline Epipteric & 17 & 2 & 0 & 1.35 & 0 \\
\hline Stellate & 1 & & & \\
\hline
\end{tabular}

a: $p<0.001$ compared to rest of the types of the pterion; $b$ : $p<0.01$ compared to the right side

Table II. Symmetry of the pterion in South Indian adult male and female skulls

\begin{tabular}{|c|c|c|c|c|}
\hline \multicolumn{2}{|c|}{ Types of the pterion } & \multirow{2}{*}{$\begin{array}{c}\text { Total } \\
(\mathrm{n}=50)\end{array}$} & \multicolumn{2}{|c|}{ Sex } \\
\hline Right side & Left side & & Male $(n=37)$ & Female $(n=13)$ \\
\hline Sphenoparietal & Sphenoparietal & $70^{\mathrm{a}}$ & 70.27 & 69.23 \\
\hline Frontotemporal & Frontotemporal & 4 & 0 & $15.38^{\mathrm{c}}$ \\
\hline Epipteric & Epipteric & 10 & 10.81 & 7.69 \\
\hline Stellate & Stellate & 0 & 0 & 0 \\
\hline Sphenoparietal & Frontotemporal & 0 & 0 & 0 \\
\hline Sphenoparietal & Epipteric & 0 & 0 & 0 \\
\hline Sphenoparietal & Stellate & 0 & 0 & 0 \\
\hline Frontotemporal & Sphenoparietal & 0 & 0 & 0 \\
\hline Epipteric & Sphenoparietal & 14 & 16.22 & 7.70 \\
\hline Stellate & Sphenoparietal & 2 & 2.7 & 0 \\
\hline Frontotemporal & Epipteric & 0 & 0 & 0 \\
\hline Frontotemporal & Stellate & 0 & 0 & 0 \\
\hline Epipteric & Frontotemporal & 0 & 0 & 0 \\
\hline Stellate & Frontotemporal & 0 & 0 & 0 \\
\hline Epipteric & Stellate & 0 & 0 & 0 \\
\hline Stellate & Epipteric & 0 & 0 & 0 \\
\hline \multicolumn{2}{|l|}{ Total } & 100 & 100 & 100 \\
\hline \multicolumn{2}{|c|}{ Bilaterally symmetrical } & $84^{\mathrm{b}}$ & 81.08 & $92.30^{\mathrm{d}}$ \\
\hline \multicolumn{2}{|c|}{ Unilateral occurrence } & 16 & 18.92 & 7.70 \\
\hline
\end{tabular}

Data are expressed as percentage of skulls. a:p $<0.001$ compared to rest of the types of pterion; b:p $<0.01$ compared to unilateral occurrence; c:p $<0$. 0001 compared to male skulls; $\mathrm{d}: \mathrm{p}<0.05$ compared to female skulls

Table III. Incidence of various types of epipteric bones in South Indian adult skulls

\begin{tabular}{|l|c|}
\hline Types of epipteric bone $(\mathrm{n}=17)$ & Incidence \\
\hline Os epiptericum proprium & $7(41.2 \%)$ \\
\hline Os epiptericum bilateralum & 0 \\
\hline Os epiptericum antericus & 0 \\
\hline Os epiptericum postericus & $9(52.9 \%)$ \\
\hline Os epiptericum supericus & 0 \\
\hline Os epiptericum infericus & 0 \\
\hline Ossa epipterica & 0 \\
\hline Os epitericum anterosuperius & $1(5.9 \%)$ \\
\hline
\end{tabular}




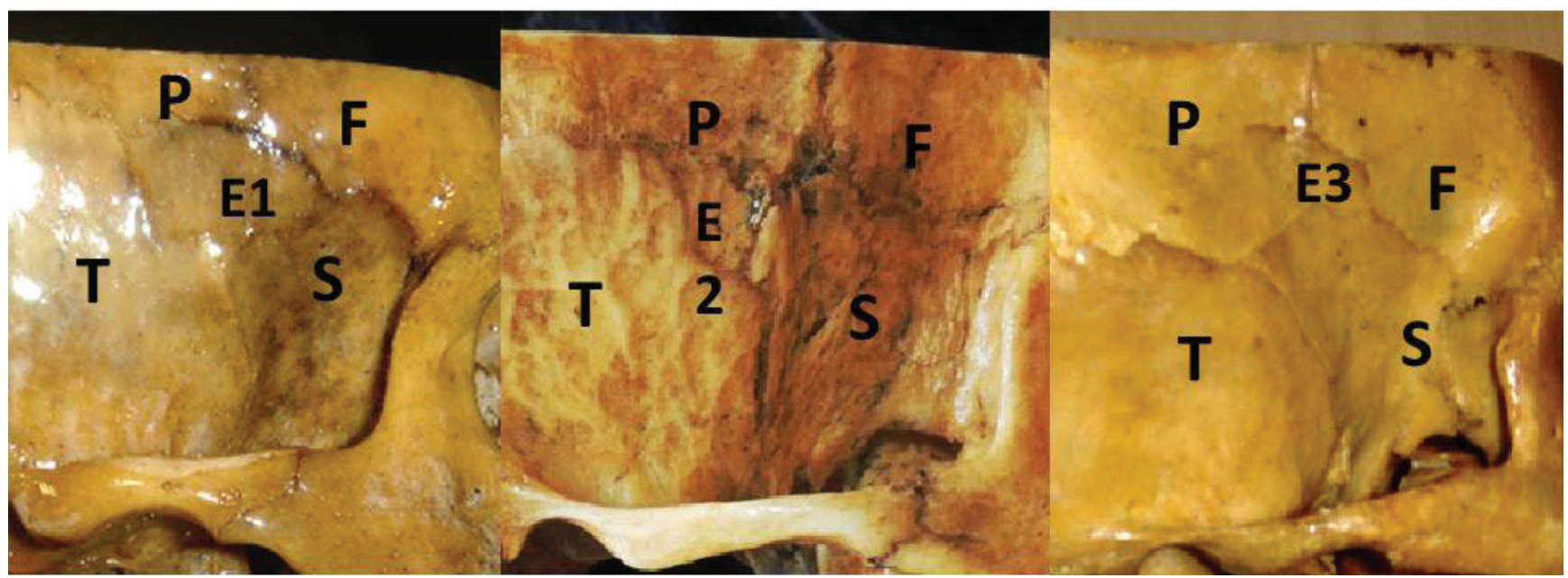

Figure 4: Various types of epipteric bones found in the present study
$\mathrm{F}=$ Frontal bone
$\mathrm{P}=$ Parietal bone
$\mathrm{T}=$ Temporal bone
$\mathrm{S}=$ Sphenoid bone
$\mathrm{E} 1=$ Os epiptericum proprium
$\mathrm{E} 2=$ Os epipterium posterius
$\mathrm{E} 3=$ Os epipterium anterosuperius

three times higher (right $76 \%$ and left $70 \%$ ) than anterior type (right $24 \%$ and left $30 \%$ ). Both males and females had significantly higher incidence of posterior (77.1 V/s 61.6) when compared to anterior ones (22.9 V/s 38.4) (Table IV).

\section{Metrical parameters}

The linear measurements taken from the center of the pterion to various internal and external landmarks are represented as mean and standard deviations in Table V. On the external aspect of the skull, zygomatic arch and frontozygomatic suture was at an average distance of $3.97 \pm 0.10 \mathrm{~cm}$ and $3.27 \pm 0.06 \mathrm{~cm}$ from the center of the pterion respectively. On the internal aspect of the skull, mean distances measured from the corresponding point of the center of pterion were $4.02 \pm 0.12 \mathrm{~cm}$ horizontally to the lateral margin of the optic canal and $0.97 \pm 0.09 \mathrm{~cm}$ to the lateral end of the ridge on the lesser wing of the sphenoid. The mean distance measured from the pterion to the stem of MMA was 0.99 $\pm 0.07 \mathrm{~cm}$ and to frontal ramus of MMA was $0.58 \pm 0.12$ $\mathrm{cm}$. The mean distance from the pterion to the anterior end of frontal ramus was $3.87 \pm 0.11 \mathrm{~cm}$ and to the posterior end of parietal ramus was $10.13 \pm 0.24 \mathrm{~cm}$. There were no statistically significant difference when the right and left sides were compared. When we compared male and female skulls, all the parameters except distance from the pterion to nearest point of branch of MMA and distance from pterion to anterior end of anterior ramus of MMA were not significantly higher in males.

\section{Discussion}

Knowledge and understanding of the type and location of the pterion and its relation to surrounding bony landmarks is important in neurosurgery. In addition presence of more than one sutural bone at the pterion is of radiological significance as sutural bones may be mistaken for fractures of the skull in cases of trauma of the pterion.

The observations of the present study indicate that the human skull is not bilaterally symmetrical with respect to the type of pterion. The reasons for the asymmetrical patterns are not known. Therefore, one should be aware of this asymmetry while operating in the region of the pterion especially on the left side as Broca's speech area and middle cerebral artery lie at this point.

In the present study the sphenoparietal type of pterion was the most common type which is in agreement with other studies [9-17] (Table-VI). The high occurrence of the sphenoparietal pterion could have an evolutionary basis [18] as this is the most common type in biped primates such as bonobos and orangutans [19]. It has been shown that the development of calvarial bones is tightly coordinated with the growth of the brain and requires interactions between different tissues in the sutures [20]. Increase in brain size in primates [19] must have caused morphological changes in neurocranium that led to meeting of greater wing of sphenoid and parietal bone.

The incidence of the frontotemporal type of pterion has also been observed to vary in different ethnic groups. In the 
Table IV. Classification of the pterion in South Indian adult skulls based on their position

\begin{tabular}{|c|c|c|c|c|c|}
\hline Pterion & $\begin{array}{c}\text { Total } \\
(\mathrm{n}=100)\end{array}$ & $\begin{array}{c}\text { Right } \\
(\mathrm{n}=50)\end{array}$ & $\begin{array}{c}\text { Left } \\
(\mathrm{n}=50)\end{array}$ & $\begin{array}{c}\text { Males } \\
(\mathrm{n}=74)\end{array}$ & $\begin{array}{c}\text { Females } \\
(\mathrm{n}=26)\end{array}$ \\
\hline High & $33 \%$ & $40 \%$ & $26 \%$ & $41.8 \%$ & $11.5 \%^{\mathrm{a}}$ \\
\hline Low & $6 \%$ & 0 & $3 \%$ & $8.1 \%$ & 0 \\
\hline Anterior & $17 \%$ & $12 \%$ & $22 \%$ & $3.2 \%$ & $38 \%^{\mathrm{a}}$ \\
\hline Posterior & $23 \%$ & $36 \%$ & $30 \%$ & $31.0 \%$ & $7.6 \%{ }^{\mathrm{b}}$ \\
\hline
\end{tabular}

$\mathrm{a}: \mathrm{p}<0.00 ; \mathrm{b}: \mathrm{p}<0.01$ compared to male skull

Table V. Linear distance $(\mathrm{cm})$ from the pterion to specific identifiable bony landmarks

\begin{tabular}{|l|c|c|c|c|c|c|c|}
\hline \multirow{2}{*}{ Landmarks from the pterion } & \multicolumn{2}{|c|}{ Right side $(\mathrm{n}=50)$} & \multicolumn{2}{|c|}{ Left side $(\mathrm{n}=50)$} & \multicolumn{2}{c|}{ Gender } & Total $(\mathrm{n}=100)$ \\
\cline { 2 - 7 } & $\begin{array}{c}\text { Mean } \\
\pm \mathrm{SD}\end{array}$ & Range & Mean $\pm \mathrm{SD}$ & Range & Male $\mathrm{n}=74$ & Female $\mathrm{n}=26$ & Mean \pm SD \\
\hline $\begin{array}{l}\text { A (Vertical distance from the center of } \\
\text { the pterion to the zygomatic arch) }\end{array}$ & $4.05 \pm 0.43$ & $3.27-5.40$ & $3.90 \pm 0.36$ & $3.03-5.04$ & $4.05 \pm 0.10$ & $3.75 \pm 0.10$ & $3.975 \pm 0.10$ \\
\hline $\begin{array}{l}\text { B (Distance from the center of the } \\
\text { pterion to the posterolateral aspect of the } \\
\text { frontozygomatic fissure) }\end{array}$ & $3.32 \pm 0.50$ & $2.00-4.37$ & $3.23 \pm 0.53$ & $1.64-4.14$ & $3.37 \pm 0.06$ & $3.01 \pm 0.04$ & $3.27 \pm 0.06$ \\
\hline $\begin{array}{l}\text { C (Horizontal distance from the center } \\
\text { of the pterion to the lateral margin of the } \\
\text { optic canal) }\end{array}$ & $4.11 \pm 0.39$ & $3.24-4.86$ & $3.94 \pm 0.48$ & $2.2-4.83$ & $4.11 \pm 0.10$ & $3.76 \pm 0.15$ & $4.02 \pm 0.12$ \\
\hline $\begin{array}{l}\text { D (Distance from the central of the } \\
\text { pterion to the lateral end of the ridge on } \\
\text { the lesser wing of the sphenoid) }\end{array}$ & $1.04 \pm 0.47$ & $0.33-1.99$ & $0.90 \pm 0.39$ & $0.26-1.99$ & $1.01 \pm 0.07$ & $0.86 \pm 0.17$ & $0.97 \pm 0.09$ \\
\hline $\begin{array}{l}\text { E (Distance from the pterion to nearest } \\
\text { point of stem of MMA) }\end{array}$ & $1.05 \pm 0.77$ & $0-2.3$ & $0.94 \pm 0.86$ & $0-2.2$ & $1.00 \pm 0.07$ & $1.00 \pm 0.09$ & $0.99 \pm 0.07$ \\
\hline $\begin{array}{l}\text { F (Distance from the pterion to nearest } \\
\text { point of branch of MMA) }\end{array}$ & $0.5 \pm 0.58$ & $0-2.5$ & $0.67 \pm 0.76$ & $0-2.8$ & $0.50 \pm 0.03$ & $0.86 \pm 0.43$ & $0.58 \pm 0.12$ \\
\hline $\begin{array}{l}\text { G (Distance from the pterion to anterior } \\
\text { end of anterior ramus of MMA) }\end{array}$ & $3.95 \pm 1.04$ & $1.77-5.49$ & $3.79 \pm 1.24$ & $0.29-6.39$ & $3.83 \pm 0.11$ & $4.00 \pm 0.09$ & $3.87 \pm 0.11$ \\
\hline $\begin{array}{l}\text { H (Distance from the pterion to posterior } \\
\text { end of posterior ramus of MMA) }\end{array}$ & $9.96 \pm 1.83$ & $1.17-11.8$ & $10.30 \pm 1.42$ & $5.60-12.66$ & $10.25 \pm 0.07$ & $9.79 \pm 0.68$ & $10.13 \pm 0.24$ \\
\hline
\end{tabular}

present study, the frequency of a frontotemporal type pterion was $4 \%$ being closest to that reported in North Indians [9]. Interestingly, in the present study none of the male skulls showed the frontotemporal type, the reason for this could be that the greater wing of the sphenoid in males was broader and hence there was no articulation between the frontal and temporal bones. The stellate type of pterion was observed in a small number of male skulls ( $1 \%$ ) specifically on right side. The incidence of this type in the literature varies from $0.6 \%$ to $5.17 \%[10,12,21]$.

Knowledge of epipteric types of pterion is very important for neurosurgeons since it can mislead neurosurgeons during burr hole, as the configuration of the pterion changes depending upon the number, form, extension, and location of the epipteric bones [11]. The incidence of epipteric bones is reported to be high in Indians, Japanese and Australians. Studies in the literature suggest that the incidence varies from $32.4 \%$ to $52.9 \%$ [13]. In the present study, an epipteric pterion was reported to be dominant on the right side, which has also been observed in Nigerians [11] and more common in males than in females. In skulls which have a variation in the epipteric bone, especially the os epiptericum proprium and os epiptericum anterius varieties, these may mistakably assessed to be at the most anterior margin of pterion and burr hole can then lead to penetration into orbit. [3]. In our study, os epiptericum proprium was most common.

With respect to the type of pterion, the present study showed 5 various combinations with three bilaterally symmetrical and two bilaterally asymmetrical pattern. Murphy [10] in an Australian aboriginal population showed 
16 possible combinations whereas Wandee et al. [22] showed nine combinations in a Thai population. The difference in frequency observed in different ethnic groups is probably due to differences in skull shape of these populations or due to genetic and environmental factors [11].

In the present population, we observed the incidence of a posterior positioned pterion unilaterally and according to gender to be the commonest position in contrast to high pterion in a study conducted by Saxena et al. in Indians [12]. Males had high pterion and females had low pterion. The pterion has been reported to lie $4.0 \mathrm{~cm}$ above the zygomatic arch and $3.0-3.5 \mathrm{~cm}$ behind the frontozygomatic suture
[23]. In the present study, the pterion was located $3.97 \pm 0.10$ $\mathrm{cm}$ above the zygomatic arch, and $3.27 \pm 0.06 \mathrm{~cm}$ behind the frontozygomatic suture (Table II). However, a comparative study of the distance between the center of the pterion and the zygomatic arch and frontozygomatic suture reported some differences between them. (Table VII).

An approach to through the pterion is used in surgeries to treat meningiomas, tumors of the frontal lobe, operations on Broca's area, extradural heamatomas, aneurysms of MMA, the upper basilar complex or petroclival tumors [6, 24-27]. For these the distance between the internal aspect of the pterion and the lateral end of the sphenoid ridge is useful

Table VI. Comparison of the percentage of the pterion types in different populations

\begin{tabular}{|l|l|c|c|c|c|c|}
\hline Author & Study population & $\mathrm{N}$ & Sphenoparietal & Frontotemporal & Epipteric & Stellate \\
\hline Murphy, 1956 [10] & Australian Aborigines & 388 & 73 & 7.5 & 18.5 & 1 \\
\hline Saxena et al., 1988 [12] & Nigerian & 40 & 87.79 & 10.11 & 3.79 & 5.06 \\
\hline Saxena et al., 1988 [12] & Indian & 72 & 95.3 & 3.46 & 11.79 & 1.38 \\
\hline Matsumura et al., 1991 [13] & Japanese & 614 & 79.1 & 2.6 & 17.7 & 0.6 \\
\hline Manjunath et al., 1993 [15] & South Indian & 172 & 93.55 & 3.52 & 17.3 & 2.93 \\
\hline Asala et al., 1996 [11] & Nigerian & 212 & 82.1 & 23.6 & 5.7 & - \\
\hline Lee et al., 2001 [16] & Korean & 149 & 76.5 & - & 40.3 & - \\
\hline Saxena et al., 2003 [4] & North Indian & 203 & 84.72 & 10.01 & & 5.17 \\
\hline Ersoy et al., 2003 [3] & Turkish & 300 & 87.35 & - & 8.98 & 0.2 \\
\hline Oguz et al., 2004 [5] & Turkish & 26 & 88 & 10 & 2 & - \\
\hline Mwachaka et al., 2009 [14] & Kenyan & 79 & 66 & 15.0 & 12.0 & 7.0 \\
\hline Ilknur et al., 2009 [17] & Anatolian - Byzantine (13th Century) & 16 & 87.5 & 6.25 & 6.25 & - \\
\hline Ilknur et al., 2009 [17] & Anatolian - Contemporary (20th Century) & 28 & 89.2 & 3.6 & 3.6 & 3.6 \\
\hline Zalawadia et al., 2010 [21] & Western Indian & 42 & 91.7 & 2.4 & 4.8 & 1.2 \\
\hline Wandee et al., 2011 [22] & Thai & 536 & 81.2 & 1.1 & 17.4 & 0.4 \\
\hline Present Study, 2013 & South Indian & 100 & 78 & 4 & 17 & 1 \\
\hline
\end{tabular}

Table VII. Comparison of linear distance $(\mathrm{cm})$ from the pterion to specific identifiable bony landmarks in different study populations

\begin{tabular}{|c|c|c|c|c|c|c|c|c|c|c|}
\hline Authors & \multicolumn{2}{|c|}{ Oguz et al., 2004 [5] } & \multicolumn{2}{|c|}{ Mwachaka et al., 2009 [14] } & \multicolumn{2}{|c|}{ Ilknur et al., 2009 [17] } & \multicolumn{2}{|c|}{ Zalawadia et al., 2010 [21] } & \multicolumn{2}{|c|}{ Present study } \\
\hline Population & Turk & kish & Ker & Jan & $\begin{array}{r}\text { Anatolian } \\
\text { (20th }\end{array}$ & $\begin{array}{l}\text { temporary } \\
\text { tury) }\end{array}$ & Wester & Indian & South I & Indian \\
\hline Side & Right & Left & Right & Left & Right & Left & Right & Left & Right & Left \\
\hline $\begin{array}{l}\text { Vertical distance from the center } \\
\text { of the pterion to the zygomatic } \\
\text { arch }\end{array}$ & $4.05 \pm 0.39$ & $3.85 \pm 0.25$ & $3.03 \pm 3.40$ & $3.03 \pm 4.30$ & $3.5 \pm 0.5$ & $3.5 \pm 0.5$ & $3.73 \pm 0.51$ & $3.55 \pm 0.42$ & $4.05 \pm 0.43$ & $3.90 \pm 0.36$ \\
\hline $\begin{array}{l}\text { Distance from the center of the } \\
\text { pterion to the posterolateral aspect } \\
\text { of the frontozygomatic fissure }\end{array}$ & $3.30 \pm 0.40$ & $3.44 \pm 0.39$ & $3.88 \pm 3.49$ & $3.82 \pm 3.47$ & $3.8 \pm 0.4$ & $3.9 \pm 0.4$ & $3.12 \pm 0.44$ & $2.97 \pm 0.33$ & $3.32 \pm 0.50$ & $3.23 \pm 0.53$ \\
\hline $\begin{array}{l}\text { Horizontal distance from the } \\
\text { center of the pterion to the lateral } \\
\text { margin of the optic canal }\end{array}$ & $4.39 \pm 0.40$ & $4.36 \pm 0.40$ & & & - & - & $4.52 \pm 0.32$ & $4.37 \pm 0.23$ & $4.11 \pm 0.39$ & $3.94 \pm 0.48$ \\
\hline $\begin{array}{l}\text { Distance from the center of the } \\
\text { pterion to the lateral end of the ridge } \\
\text { on the lesser wing of the sphenoid }\end{array}$ & $1.40 \pm 0.33$ & $1.48 \pm 0.32$ & & & - & - & $1.36 \pm 0.35$ & $1.33 \pm 0.22$ & $1.04 \pm 0.47$ & $0.90 \pm 0.39$ \\
\hline
\end{tabular}


information for the operation. In the present study, this distance was $0.97 \pm 0.09 \mathrm{~cm}$ (Table IV) while this distance in comparison to Turkish, Thais and Western Indian skulls was greater (Table VII). The pterional approach can also be used to access the optic canal [28], where the distance between the internal aspect of the pterion and the lateral margin of the optic canal is a crucial parameter. The mean of this distance in the present study was $4.02 \pm 0.12 \mathrm{~cm}$ (Table IV) but Thai population had smaller distance of $3.89 \pm 3.76 \mathrm{~cm}$.

Accurate knowledge of the location and relations of the pterion is important in particular with respect to the course of the branches of the MMA. In the present study, in 10\% cases the stem of MMA was in contact with the pterion whereas in $14 \%$ of cases the frontal branch was directly in contact with the pterion. Damage to stem or frontal branch of MMA will hamper the blood supply to the dura mater, periosteum of the bone and bone marrow approximately $3.87 \pm 0.11 \mathrm{~cm}$ in front of the pterion and approximately $10.13 \pm 0.24 \mathrm{~cm}$ away from pterion. Hence, during a pterional approach when a burr hole is made this distance should be kept in mind as chances of damaging MMA or its frontal branch may occur.

\section{Conclusion}

To conclude, an accurate knowledge of the location of the pterion is important in relation to surgical interventions, particularly with respect to the course of the branches of the middle meningeal artery and to Broca's motor speech area on the left side. The distances between the pterion and the lesser wing of the sphenoid and the optic canal are of practical importance in surgical approaches to these regions via the pterion. Types and the position of the pterion vary among individuals and different racial groups and thus the need for accurate and up-to-date data when performing intracranial surgery guided by recognizable bony landmarks is essential. Therefore, preoperative radiographic assessment (CT images, magnetic resonance radiographs) of the pterion should be confirmed in determining a safe location for performing surgical and microsurgical procedures.

\section{References}

1. Moore KL, Dalley AF, Agur AMR. Clinically Oriented Anatomy. Philadelphia: Lippincott Williams \& Wilkins, 2010.

2. Greenberg MS. Handbook of Neurosurgery. NewYork: Thieme Medical Publishers, 2006.
3. Ersoy M, Evliyaoglu C, Bozkurt MC, Konuksan B, Tekdemir I, Keskil IS. Epipteric bones in the pterion may be surgical pitfall. Minim Invasive Neurosurg 2003;46:364-5.

4. Saxena RC, Bilodi AK, Mane SS, Kumar A. Study of pterion in skulls of awadh area-in and around Lucknow. Kathmandu Univ Med J 2003; 1:32-3.

5. Oguz O, Sanli SG, Bozkir MG, Soames RW. The pterion in Turkish male skulls. Surg Radiol Anat 2004; 26:220-4. doi: 10.1007/s00276-003-0210-2

6. Lang J. The pterion region and its clinically important distance to the optic nerve. 2. Pterion region, distance to the optic nerve, dimensions and shape of the recess of the temporal pole. Neurochirurgia (Stuttg) 1984;27:31-5. doi:10.1055/s-2008-1053721

7. Lovejoy CO, Meindl RS, Mensforth RP, Barton TJ. Multifactorial determination of skeletal age at death: a method a blind tests of its accuracy. Am J Phys Anthropol 1985 ;68:1-14. doi:10.1002/ajpa.1330680102

8. Wang Q, Opperman LA, Havill LM, Carlson DS, Dechow PC. Inheritance of sutural pattern at the pterion in Rhesus Monkey skulls. Anat Rec Discov Mol Cell Evol Biol 2006; 288:1042-9. doi: 10.1002/ar.a.20373

9. Agarwal AK, Singh PJ, Gupta SC, Gupta CD. Pterion formation and its variations in the skulls of Northern India. Anthropol Anz 1980; 38: 265-9.

10. Murphy T. The pterion in Australian Aborigine. Am J Phys Anthropol 1956; 14: 225-44. doi: 10.1002/ajpa.1330140218

11. Asala SA, Mbajiourgu FE .Epigenetic variation in the Nigerian skulls: sutural pattern at the pterion. East African Med J 1996; 73: 484-6.

12. Saxena SK, Jain SP, Chowdhary DS .A comparative study of pterion formation and its variations in the skulls of Nigerians and Indians. Anthropol Anz 1988; 46: 75-83.

13. Matsumura G, Kida K, Ichikawa R, Kodama G. Pterion and epipteric bones in Japanese adults and fetuses, with special reference to their formation and variations. Kaibogaku Zasshi 1991; 66: 462-71.

14. Mwachaka PM, Hassanali J, Odula P. Sutural morphology of the pterion and asterion among adult Kenyans. Braz J Morphol Sci 2009; 26:4-7.

15. Manjunath KY, Thomas IM. Pterion variants and epipteric ossicles in South Indian skulls. J Anat Soc India 1993;42:8594.

16. Lee UY, Park DK, Kwon SO, et al . Morphological analysis of pterion in Korean. Korean J Phys Anthropo 2001; 14:2819.

17. Ilknur A, Mustafa KI, Sinan B. A comparative study of variation of the pterion of human skulls from $13^{\text {th }}$ and $20^{\text {th }}$ century Anatolia. Int. J Morphol 2009;27:1291-8.

18. Liu YH, Tang Z, Kundu RK, et al. Msx2 gene dosage influences the number of proliferative oesteogenic cells in growth centres of the developing murine skull: a possible mechanism for MSX2-mediated craniosynostosis in humans. Dev Bio 1999; 205: 260-74. doi:10.1006/dbio.1998.9114

19. Ashley-Montagu, MF. The anthropological significance of the pterion in the Primates. Am J Phys Anthropol1933;18: 159-336. doi: 10.1002/ajpa.1330180216 
20. Lee UY, Park DK, Kwon SO, Paik DJ, Han SH. FGF-,BMPand Shh-mediated signaling pathways in the regulation of cranial suture morphogenesis and calvarial bone development. Development 1998;125:1241-51.

21. Zalawadia DA, Vadgama DJ, Ruparelia DS, Patel DS, Patel DSV. Morphometric study of pterion in dry skull of Gujarat region. NJIRM. 2010; 1: 25-9.

22. Wandee A, Supin C, Vipavadee C, Paphaphat T, Noppadol P. Anatomical consideration of pterion and its related references in Thai dry skulls for pterional surgical approach . J Med Assoc Thai 2011; 94: 205-14.

23. Williams LP, Bannister LH, Berry MM, Collins P, Dyson M, Dussek JE, Ferguson MWJ. Gray's Anatomy. London: Churchill Livingstone, 1998 .
24. Escosa-Bagé M, Sola RG, Liberal-González R, Caniego JL, Castrillo-Cazón C. Fusiform aneurysm of the middle cerebral artery. Rev Neurol 2002; 34: 655-8.

25. Heros RC, Lee SH .The combined pterional/anterior temporal approach for aneurysms of the upper basilar complex: technical report. Neurosurgery 1993;33: 244-50.

26. Potapov AA, Yeolchiyan SA, Tcherekaev VA, et al . Removal of cranio-orbital foreign body by a supraorbital-pterion approach. J Craniofac Surg 1996;7: 224-7.

27. Yu C, Jiang T, Guan S. Lateral approaches for treatment of petroclival region tumor. Zhonghua Yi Xue Za Zhi 1999; 79:894-6.

28. Schick U, Dott U, Hassler W. Surgical management of meningiomas involving the optic nerve sheath. J Neurosurg 2004; 101: 951-9. doi::10.3171/jns.2004.101.6.0951 